\title{
PKM PELATIHAN PERAKITAN ELEKTRONIKA SEBAGAI BEKAL KETERAMPILAN GENERASI MILENIAL DI KOTA TASIKMALAYA
}

\author{
Muhammad Aris Risnandar'), Aceng Sambas'), Shofiatul Ula ${ }^{2)}$ \\ ${ }^{1)}$ Prodi Teknik Elektro, Fakultas Teknik, Universitas Muhammadiyah Tasikmalaya \\ ${ }^{2)}$ Prodi Teknik Mesin, Fakultas Teknik, Universitas Muhammadiyah Tasikmalaya \\ e-mail: aris_elektro@umtas.ac.id.
}

\begin{abstract}
The Ar-Ridho PKBM and the Majelis Pemberdayaan Masyarakat (MPM) of the Muhammadiyah Regional Leadership of the city of Tasikmalaya have a large contribution to the community empowerment program in the city of Tasikmalaya. However, the institution has limitations related to training, limited funds, human resources, and other supporting facilities. The problem is related to the lack of Tasikmalaya city people who have skills in the field of technology, so people do not have good skills in dealing with global competition. Therefore, we conduct electronic assembly training activities with a focus on providing electronic assembly skills for the millennial generation. The material presented includes the concept of introducing electronic components, measuring electronics and assembling light sensors on garden lights. With the provision of skills such as this millennial generation is expected to have the basic skills that are used as provisions for entrepreneurship and become productive economically and socially.
\end{abstract}

Keywords: millennial generation, electronic components, light sensors

\begin{abstract}
Abstrak
PKBM Ar-Ridho dan Majelis Pemberdayaan Masyarakat (MPM) Pimpinan Daerah Muhammadiyah kota Tasikmalaya memiliki kontribusi besar dalam program pemberdayaan masyarakat di kota Tasikmalaya. Namun saat ini, lembaga memiliki keterbatasan terkait dengan pelatihan, keterbatasan dana, sumber daya manusia dan fasilitas pendukung lainya. Permasalahan tersebut berkaitan dengan minimnya masyarakat kota Tasikmalaya yang memiliki keterampilan dalam bidang teknologi, sehingga masyarakat tidak memiliki keterampilan yang baik dalam menghadapi persaingan global. Oleh karena itu, kami mengadakan kegiatan pelatihan perakitan elektronika dengan fokus pada pembekalan keterampilan perakitan elektronika bagi generasi milenial. Materimateri yang disajikan diantaranya konsep pengenalan komponen elektronika, pengukuran elektronika dan perakitan sensor cahaya pada lampu taman. Dengan adanya pembekalan keterampilan seperti ini diharapkan generasi milenial ini dapat memiliki keterampilan dasar yang dijadikan bekal untuk berwirausaha dan menjadi masyarakat yang produktif secara ekonomi maupun sosial.
\end{abstract}

Kata Kunci: Generasi milenial,komponen elektronik dan sensor cahaya

\section{PENDAHULUAN}

\section{Analisis Situasi}

Generasi milenial atau generasi Y merupakan generasi yang lahir pada tahun 1980-2000 an dan memiliki karakteristik sebagai berikut (Putra, 2006; Sabani, 2018); 1) Realistis; 2) Sangat menghargai perbedaan, lebih memilih bekerjasama daripada menerima perintah, dan sangat pragmatis ketika memecahkan persoalan; 3) Memiliki rasa optimis yang tinggi, fokus pada prestasi, percaya diri, percaya pada nilai-nilai moral dan sosial, serta menghargai adanya keragaman.

Berdasarkan karakteristik tersebut, maka generasi ini memiliki keunggulankeunggulan dibandingkan generasigenerasi sebelumnya. Namun pengelolaan sumber daya manusia yang kurang tepat, hal ini akan menjadi bumerang dalam menghadapi era globalisasi saat ini (Rinandiyana dkk, 2017; Fahrimal, 2018).

Era globalisasi merupakan suatu 
era dimana persaingan dalam berbagai aspek kehidupan menjadi tanpa batas. Hal ini menimbulkan fenomena yang unik di masyarakat, dimana masyarakat dapat bersaing secara bebas baik dalam lingkup nasional maupun internasional (Mubah, 2011; Mukhadis, 2013). Kondisi seperti ini tidak sepenuhnya memberikan pengaruh positif bagi seluruh kalangan masyarakat. Seperti hal nya di kota Tasikmalaya, menurut Badan Pusat Statistik (BPS) kota Tasikmalaya tercatat prosentase pengangguran berada pada angka 5,46\% pada tahun 2015 dan terus mengalami peningkatan menjadi $6.89 \%$ di tahun 2017 (Radar Tasikmalaya, 2018). Kondisi seperti ini tidak menguntungkan di masyarakat, dimana kondisi tersebut tidak mustahil menimbulkan permasalahan baru seperti kemiskinan.

Mitra dalam kegiatan Program Kemitraan Masyarakat (PKM) ini yaitu: Pertama, Pusat Kegiatan Belajar Masyarakat (PKBM) AR-Ridho yang berlokasi di Perum Tajur Indah, Jl. Flamboyan No. 64 RT 02/07 Kel. Panyingkiran, Kec. Indihiang, Kota Tasikmalaya (Mitra I). Kedua, Majelis Pemberdayaan Masyarakat (MPM) Pimpinan Daerah Muhammadiyah Kota Tasikmalaya yang berlokasi di Jl. K.H. Zaenal Mustofa No. 278, Cihideung, Kota Tasikmalaya (Mitra II).

Saat ini Mitra I merupakan suatu organisasi yang bergerak dalam bidang pelayanan pendidikan penyetaraan Paket B dan Paket C. Dalam prakteknya, siswa lulusan program penyetaraan ini masih harus dapat bersaing setelah menyelesaikan program penyetaraan ini bahkan persaingan untuk siswa lulusan program penyetaraan ini memiliki tantangan yang lebih berat dibanding siswa-siswa lulusan dari program pendidikan umum (SMP dan SMA). Hal ini disebabkan usia lulusan dapat dikategorikan usia yang lebih tua dibanding usia lulusan pada sekolah umum, sehingga terkadang saat melamar pekerjaan siswa lulusan program penyetaraan ini sudah tidak sesuai dengan usia yang diijinkan pada saat melamar suatu pekerjaan.

Oleh karena itu, Mitra I harus berpikir lebih kreatif agar siswa lulusannya mampu mencukupi kebutuhan hidupnya meskipun lapangan pekerjaan bagi siswa lulusannya tersebut semakin terbatas. Dengan tantangan tersebut, maka Mitra I ini membekali siswanya dengan keterampilan lain agar dapat bersaing di masyarakat. Salah satu bentuk kegiatan yang pernah dilaksanakan oleh Mitra I yaitu kegiatan pembekalan keterampilan sablon. Kegiatan seperti ini mendapat antusias yang cukup besar dari para siswanya.

Kegiatan seperti ini biasanya diselenggarakan secara insidentil. Hal ini disebabkan kurangnya pendanaan dalam mengelola kegiatan seperti ini. Meskipun Mitra ini memperoleh bantuan dari pemerintah, namun bantuan tersebut habis digunakan untuk kegiatan-kegiatan inti pembelajaran. Sehingga kegiatan pelatihan seperti ini baru dapat terlaksana jika ada donatur dari pihak eksternal dan berimbas pada jumlah kegiatan yang terbatas. Selain jumlah pelatihan yang terbatas karena kurangnya dana dan fasilitas, kegiatan seperti ini juga terbentur dengan minimnya sumber daya manusia dengan kompetensi yang beragam untuk memberikan bekal keterampilan bagi siswanya sehingga kegiatan yang dilaksanakan menjadi monoton dan kurang bervariatif.

\section{Permasalahan Mitra dan Penentuan Prioritas Masalah}

Berdasarkan uraian sebelumnya, permasalahan utama kedua mitra yaitu terbatasnya dana, fasilitas, dan kompetensi sumber daya manusia yang mendukung sehingga variasi kegiatan pemberdayaan masyarakat melalui pembekalan keterampilan bagi masyarakat menjadi kurang bervariatif. Pelatihan keterampilan dalam bidang teknologi khususnya keterampilan elektronika, menjadi salah 
satu alternatif bagi masyarakat untuk membuka pola pikir dalam menerapkan konsep-konsep dasar teknologi. Secara garis besar, permasalahan yang dihadapi mitra saat ini yaitu kurangnya modal biaya dalam mengelola program pelatihan keterampilan. Selain itu kurangnya fasilitas pendukung yang dimiliki oleh kedua mitra ini, misalnya dalam memperoleh keterampilan elektronika, keterampilan tersebut tidak dapat dimiliki langsung secara otodidak dimana dalam memperoleh keterampilan seperti ini diperlukan adanya arahan dan bimbingan dari pihak-pihak yang berkompeten. Kurangnya kegiatan pelatihan keterampilan dalam bidang teknologi ini, masyarakat kota Tasikmalaya masih sebatas user-only dalam bidang teknologi. Padahal dalam persaingan global saat ini, masyarakat harus lebih kreatif dan bukan hanya sebagai pengguna bahkan penonton saja. Hal ini disebabkan kurangnya pengetahuan dalam bidang teknologi dan masih menganggap teknologi ini merupakan suatu hal yang rumit Berdasarkan analis tersebut, maka rincian permasalahan kedua mitra yang paling menonjol diantaranya:

a. Masyarakat kota Tasikmalaya masih menganggap teknologi suatu hal yang rumit dan hanya bisa dikerjakan oleh ahli;

b. Minimnya kegiatan pelatihan keterampilan bagi masyarakat di kota Tasikmalaya yang notabene mengandalkan donatur dari pihak eksternal;

c. Minimnya pemberi materi kegiatan pelatihan dalam bidang teknologi

\section{Solusi yang Ditawarkan}

Solusi yang ditawarkan dalam kegiatan pengabdian kepada masyarakat ini berfokus pada pemberian pelatihan keterampilan perakitan elektronika sederhana bagi generasi milenial di kota Tasikmalaya. Pemberian materi pelatihan dilakukan secara bertahap, dimana secara konsep pemberian materi ini mengacu pada pemberian materi mengenai:

1. Pemahaman Teknologi, tahap ini dilakukan dengan cara memberikan pemahaman bagi peserta pelatihan mengenai peran teknologi dalam kehidupan sehari-hari serta prinsipprinsip dasar pentingnya materi-materi yang akan diberikan selama pelatihan.

2. Pemahaman Konsep Dasar Elektro/Elektronika, tahap ini dilakukan dengan cara memberikan konsepkonsep dasar elektro/ elektronika, pengenalan komponen-komponen elektronika dasar, serta konsep dan cara pengukuran dalam bidang elektro/elektronika serta cara-cara pembuatan rangkaian elektronika beserta fungsi sederhananya.

3. Perakitan Rangkaian Elektronika, tahap ini dilakukan dengan cara memberikan cara-cara perakitan rangkaian elektronika sederhana serta memberikan pengalaman langsung kepada peserta pelatihan untuk melakukan perakitan rangkaian elektronika yang telah disesuaikan dengan materi pelatihan dengan arahan pemateri pelatihan.

4. Perakitan Kemasan Produk, tahap ini dilakukan dengan cara memberikan pengalaman langsung kepada peserta pelatihan untuk melakukan perakitan kemasan produk yang disesuaikan dengan rangkaian elektronika yang telah dibuat pada tahap sebelumnya. Adapun desain kemasan produk yang dibuat, mengacu pada pengarahan dari pemateri dengan mempertimbangkan aspek teknis maupun ekonomis peralatan sehingga produk tersebut dapat untuk digunakan sehari-hari.

Evaluasi Produk, tahap ini dilakukan dengan cara evaluasi produk yang dihasilkan selama pelatihan. Evaluasi produk ini dititikberatkan pada tingkat penggunaan produk apakah produk tersebut mudah digunakan (user friendly) 
atau tidak serta mengevaluasi tingkat keamanan produk.

\section{METODE}

Metode pelaksanaan yang digunakan dalam Program Kemitraan Masyarakat (PKM) ini mengacu pada pemberian pelatihan keterampilan perakitan elektronika sederhana bagi generasi milenial di kota

Tasikmalaya. Untuk menunjang terlaksananya kegiatan dengan baik, maka diperlukan rencana penyusunan tahapan pelaksanaan kegiatan. Adapun tahapan pelaksanaan kegiatan pengabdian kepada masayarakat yang diusulkan yaitu:

a) Koordinasi Kelembagaan, dilakukan untuk sinkronisasi jadwal pelatihan yang akan diselenggarakan. Sinkronisasi jadwal pelatihan ini dilakukan secara bersama-sama, baik mitra maupun pengusul serta pihak terkait lainnya (dalam hal ini Universitas Muhammadiyah Tasikmalaya selaku penyedia tempat pelatihan sekaligus pihak yang memiliki fasilitas yang dibutuhkan untuk menunjang kegiatan pelatihan. Hasil dari koordinasi kelembagaan ini yaitu memperoleh kesepakatan mengenai waktu pelaksanaan kegiatan pelatihan serta daftar calon peserta pelatihan yang diajukan oleh pihak mitra.

b) Penyusunan Modul Pelatihan, disusun berdasarkan materi-materi yang akan ditawarkan dalam kegiatan pengabdian kepada masyarakat. Penyusunan modul pelatihan ini dilaksanakan oleh tim pengusul. Hasil dari penyusunan modul pelatihan ini yaitu modul pelatihan yang akan digunakan bagi peserta selama mengikuti pelatihan.

c) Pembelian Bahan, yaitu pembelian bahan-bahan yang akan digunakan selama pelatihan seperti komponen elektronika, akrilik, dsb. Pembelian bahan dilakukan secara bertahap, dimana tahap pertama pembelian bahan difokuskan pada uji coba rangkaian. Setelah uji coba rangkaian tersebut selesai dilaksanakan, kemudian dilakukan pembelian bahan dengan skala besar (untuk kebutuhan kegiatan pelatihan). Hasil dari pembelian bahan ini yaitu pemenuhan kebutuhan bahan selama kegiatan pelatihan sehingga kegiatan pelatihan dapat dilaksanakan dengan baik.

d) Uji Coba Rangkaian, dilakukan oleh tim pengusul dan dibantu oleh beberapa mahasiswa. Kegiatan ini dilakukan sebagai evaluasi modul yang diberikan telah sesuai dan mampu dilaksanakan oleh peserta pelatihan. Hasil uji coba rangkaian ini yaitu kesesuaian modul pelatihan dengan peralatan yang digunakan dan mampu diterapkan oleh peserta pelatihan.

e) Pelaksanaan Kegiatan Pelatihan, dilaksanakan sesuai dengan waktu yang ditentukan pada saat koordinasi kelembagaan. Pelaksanaan pelatihan ini dilaksanakan minimal sebanyak 8 kali pertemuan (disesuaikan dengan materi yang diberikan). Adapun jumlah kelompok yang ditetapkan dalam kegiatan ini yaitu minimal sebanyak 10 kelompok dimana masing-masing kelompok terdiri dari 2-3 orang peserta. Peserta kegiatan berasal dari dua mitra yang telah ditentukan sebelumnya. Pelaksanaan kegiatan pelatihan ini dilaksanakan di Universitas Muhammadiyah Tasikmalaya. Hasil pelaksanaan kegiatan pelatihan ini yaitu adanya produk hasil pelatihan berupa perakitan sensor cahaya pada lampu taman sederhana serta evaluasi mengenai tingkat penggunaan produk dan tingkat keamanan produk.

\section{HASIL DAN PEMBAHASAN}

\section{Tahap Teori Dasar Elektronika}

Pelaksanaan kegiatan ini merupakan kegiatan pelatihan pertama. Para peserta kegiatan diberikan pre-test 
yang menggambarkan tingkat pemahaman peserta dalam mengikuti pelatihan ini. Berdasarkan hasil pre-test ini, mayoritas peserta tidak mengetahui prinsip-prinsip dasar elektronika.

Jumlah peserta pelatihan pada hari pertama yaitu sekitar 30 orang yang terdiri dari mitra PKBM Ar-Ridho maupun MPM PDM Kota Tasikmalaya. Kegiatan pelatihan dapat dilihat pada Gambar 1. Peserta tersebut dibagi menjadi 10 kelompok kecil. Namun dalam kegiatan ini peserta dari PKBM Ar-Ridho belum menunjukkan partisipasi yang memuaskan karena peserta pelatihan masih didominasi oleh peserta dari MPM PDM Kota Tasikmalaya. Peserta dari MPM PDM Kota Tasikmalaya didominasi oleh masyarakat umum yang berprofesi sebagai wirausaha, bahkan ada sebagian dari kalangan guru.

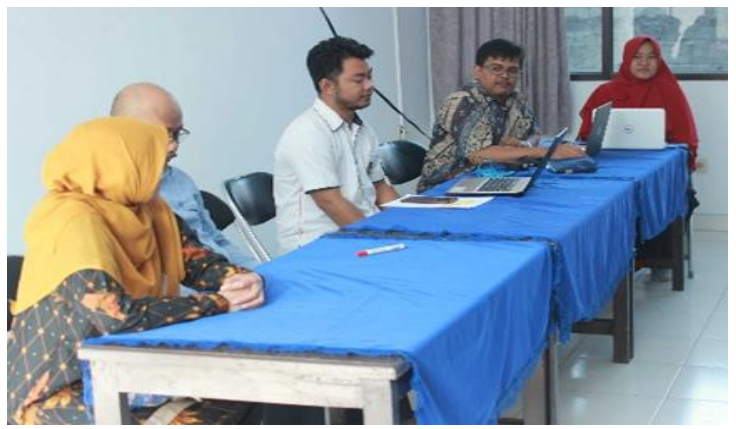

(a)

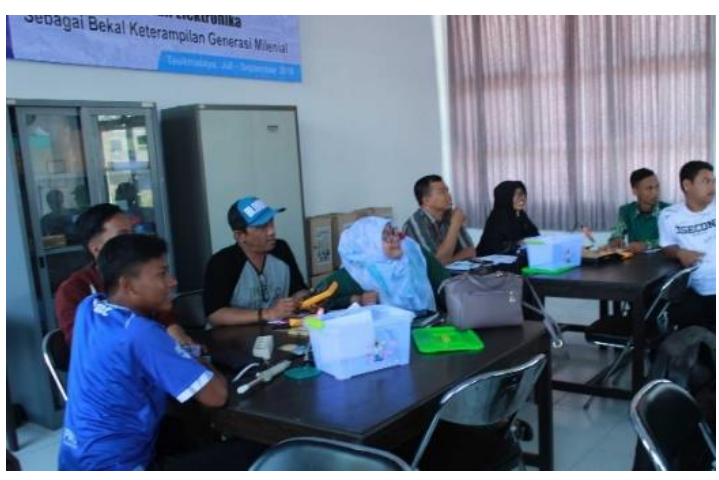

(b)

Gambar 1. (a) Pembukaan workshop dan (b) Pemberian Materi workshop

Menurut pimpinan PKBM Ar-Ridho yang pada saat kegiatan pertama ini membuka acara, para peserta dari PKBM ini mengalami beberapa kendala, diantaranya yaitu belum efektifnya para siswa PKBM dalam kegiatan pembelajaran sehingga informasi mengenai pelatihan belum tersosialisasi dengan baik.

\section{Alat Ukur Elektronika}

Pelaksanaan kegiatan ini merupakan kegiatan pelatihan kedua. Jumlah peserta pelatihan pada kegiatan kedua ini masih tidak terlalu berbeda dengan peserta pada pertemuan pertama. Pada pertemuan kedua ini peserta dari PKBM Ar-Ridho belum juga menunjukkan partisipasi yang memuaskan, namun ada beberapa tambahan peserta dari PKBM Ar-Ridho tersebut.

Menurut pimpinan PKBM Ar-Ridho, para peserta ini berkeinginan langsung praktek merakit komponen karena masih menganggap jika hanya pembahasan teori dasar, seolah-olah sama dengan materi yang diberikan di PKBM.

Pengalaman yang diperoleh peserta dalam kegiatan kedua ini yaitu mengenal alat ukur sederhana seperti multimeter, clamp meter, dan jangka sorong. Selain itu peserta juga praktek tentang cara menggunakan alat ukur dan langsung melakukan pengukuran komponen elektronika dasar seperti yang ditunjukkan pada Gambar 2.

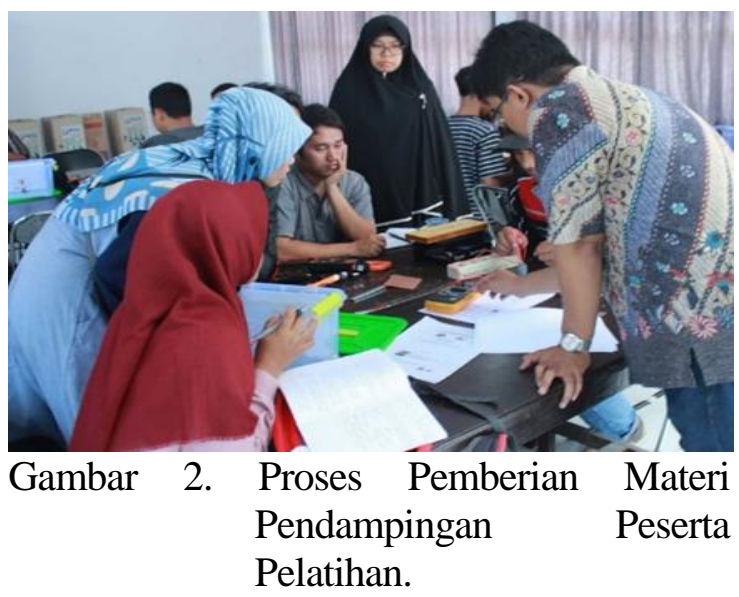

\section{Perakitan Sensor Cahaya pada Lampu Taman}

Pelaksanaan kegiatan ini merupakan kegiatan pelatihan ketiga. Pengalaman yang diperoleh peserta dalam kegiatan ketiga ini yaitu mampu membaca skema rangkaian 
sederhana dan mempraktekan perakitan komponen menggunakan PCB matriks. Rangkaian sederhana yang digunakan dalam kegiatan ketiga ini yaitu membuat rangkaian dasar dalam menggunakan sensor cahaya. Sehingga para peserta diberi pemahaman bagaimana membuat sensor untuk lampu taman otomatis.

Seluruh kelompok dapat menyelesaikan rangkaian yang diberikan, meskipun ada beberapa kelompok yang harus diberi pendampingan yang lebih intens. Dalam hal ini, tim PKM dibantu oleh beberapa mahasiswa yang terlibat aktif dalam membantu peserta pelatihan.

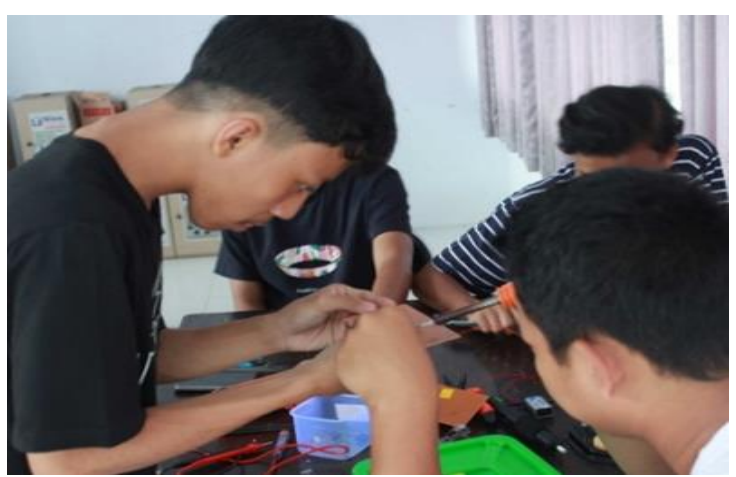

(a)

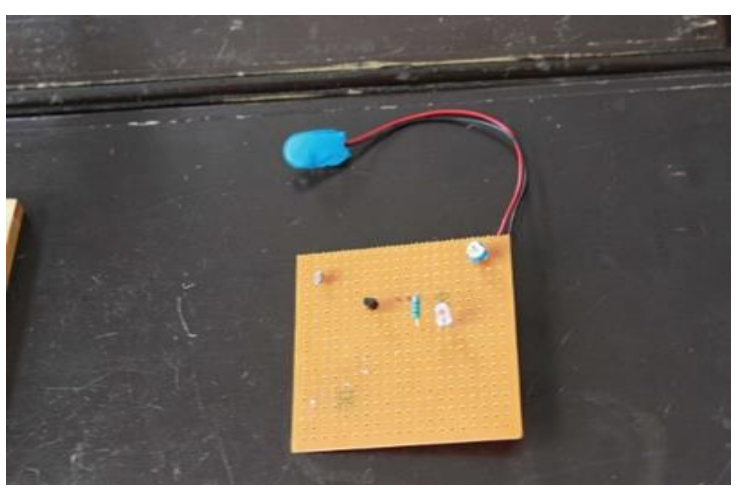

(b)

Gambar 3. (a) Kegiatan menyolder, (b) Hasil Perakitan Sensor Cahaya

\section{SIMPULAN}

\footnotetext{
Pelatihan elektronika untuk generasi milenial telah dilaksanakan dengan baik dan berjalan lancar. Kegiatan ini dilakukan selama 3 pertemuan dengan materi yang disampaikan adalah pengenalan komponen elektronika, pengukuran elektronika pada resistor dan
}

perakitan sensor cahaya pada lampu taman. Diharapkan dengan adanya pelatihan ini generasi milenial mendapakan untuk berwirausaha dan menjadi masyarakat yang produktif secara ekonomi maupun sosial.

\section{UCAPAN TERIMA KASIH}

Terima kasih disampaikan kepada Direktorat Riset dan Pengabdian Masyarakat (DRPM) Kementerian Riset, Teknologi, dan Pendidikan Tinggi Republik Indonesia yang telah mendanai Program Kemitraan Masyarakat (PKM) dengan nomor kontrak 2843/L4/PP/2019, sehingga kegiatan ini dapat dilaksanakan dengan lancar. Selanjutnya tim pengusul juga mengucapkan kepada seluruh civitas akademika Universitas Muhammadiyah Tasikmalaya khususnya Lembaga Penelitian dan Pengabdian kepada Masyarakat (LPPM) yang telah memberikan dukungan sehingga kegiatan ini dapat berjalan dengan baik. Tak lupa juga kami ucapkan terima kasih kepada kedua mitra yaitu PKBM AR-Ridho dan MPM PDM Kota Tasikmalaya yang telah berpartisipasi aktif dalam kegiatan ini.

\section{DAFTAR PUSTAKA}

Fahrimal, Y. 2018. Netiquette: Etika Jejaring Sosial Generasi Milenial dalam Media Sosial. Jurnal Penelitian Pers dan Komunikasi Pembangunan, vol. 22, no. 1, 6978.

Mubah, A. S. 2011. Strategi Meningkatkan Daya Tahan Budaya Lokal dalam Menghadapi Arus Globalisasi. Jurnal Unair, vol. 24, no. $4,302-308$.

Mukhadis, A. 2013. Sosok Manusia Indonesia Unggul dan Berkarakter dalam Bidang Teknologi Sebagai Tuntutan Hidup di Era Globalisasi. Jurnal Pendidikan Karakter, vol. 2, no. 2, 1-10. 
Muhammad Aris Risnandar, dkk. PKM Pelatihan Perakitan Elektronika...

Putra, Y. S, 2006. Theoritical Review: Teori Perbedaan Generasi," Among Makarti, vol. 9, no. 18, 123-134.

Radar Tasikmalaya, Pengangguran di Kota Tasik Masih Tinggi, Kenapa?, Tasikmalaya, Jawa Barat: www.radartasikmalaya.com, 2018.

Rinandiyana, L. R., Kurniawati, A., dan Kurniawan, D. 2017. Analisis faktor-faktor yang mempengaruhi keputusan pembelian oleh generasi milenial pada industri kuliner di kota Tasikmalaya. Jurnal Ekonomi Manajemen, vol. 3, no. 1, 18-27.

Sabani, N. (2018). Generasi Millenial Dan Absurditas Debat Kusir Virtual. Informasi, 48(1), 95-108. 